\title{
Pemanfaatan Biji Karet Sebagai Bahan Baku Pembuatan Tortila Chips di RT 02 Desa Suka Maju Muaro Jambi
}

\author{
Surhaini, Rahayu Suseno*, Ulyarti, Addion Nizori, Lavlinesia \\ Program Studi Teknologi Hasil Pertanian, Fakultas Pertanian, Universitas Jambi, Indonesia \\ *Email korespondensi: rahayususeno@unja.ac.id
}

\begin{abstract}
ABSTRAK
Tujuan dari program pengabdian pada masyarakat ini adalah menciptakan kemandirian ibuibu Desa agar dapat berinovasi dan berkreativitas dalam memanfaatkan hasil samping perkebunannya, sehingga dapat menghasilkan produk yang dapat menambah pendapatan rumah tangga. Guna mencapai tujuan ini, diperlukan transfer teknologi kepada ibu-ibu pedesaan melalui pengolahan biji karet menjadi produk tortilla chip. Metode yang dilakukan dalam pelaksanaan kegiatan PPM ini adalah: (1) Sosialisasi cara mereduksi HCN biji karet sebelum dibuat tepung biji karet, (2) Demo langsung kepada ibu-ibu tentang cara pembuatan tortilla chip dengan memanfaatkan tepung biji karet, (3) memberikan Teknik pemasaran dan melatih cara pengemasan produk.
\end{abstract}

Kata Kunci: Tortilla chip, biji karet.

\section{PENDAHULUAN}

Jambi merupakan salah satu provinsi di Indonesia yang sebagian besar penghasilan masyarakatnya masih mengandalkan sektor perkebunan, salah satunya adalah perkebunan karet. Karet merupakan salah satu komoditi yang paling unggul dibandingkan dengan komoditi lain seperti kelapa sawit dan kopi. Hal ini dapat dibuktikan dengan masih banyaknya perkebunan karet disetiap wilayah di provinsi jambi. Produksi karet alam sangatlah penting untuk dikembangkan di karena tanaman ini dapat tumbuh dengan baik meskipun ditanam dilahan yang kurang subur. Di lingkungan RT 02 Desa Suka Maju kabupaten Muaro Jambi, Provinsi Jambi terdapat lahan perkebunan karet milik warga yang luas. Berdasarkan hasil wawancara dengan ketua RT setempat terdapat sekitar 30 hektar kebun karet yang tersebar di masing-masing rumah warga. Terdapat $120 \mathrm{KK}$ di RT 02 Desa suka maju sekitar 75 merupakan petani yang 50 diantaranya merupakan petani karet.

Hingga saat ini pemanfaatan yang secara umum dilakukan hanyalah sebatas pengambilan getah dari batang karet atau yang sering disebut dengan menyadap. Sedangkan bagian pohon karet yang lain seperti biji karet, hanya menjadi produk sampingan yang belum termanfaatkan. Secara umum belum ada usaha pengolahan biji karet menjadi produk olahan karena keterbatasan pengetahuan ibu-ibu RT 02 Desa Suka Maju yang masih minim dalam hal mengolah biji karet. Pada biji karet terdapat senyawa beracun berupa HCN yang harus dihilangkan atau dikurangi sebelum dibuat menjadi produk. Perendaman selama 24 jam dan perebusan 1,5 jam diketahui dapat menurunkan lebih dari $98 \%$ HCN pada biji karet (Karima, 2015).

Kebanyakan tortilla yang dipasarkan terbuat dari penambahan tepung jagung. Jagung pada pembuatan Tortilla Chips dapat diganti dengan tepung biji karet. Penyuluhan yang dilakukan kepada Ibu-Ibu rumah tangga dapat memberikan ide untuk melalukan wirausaha yang dapat meningkatkan pendapatan keluarganya. Apabila jiwa wirausaha tersebut telah tumbuh harapan para pelaksana PPM ini adalah terbentuknya UMKM di antara pada warga khususnya para Ibu-Ibu rumah tangga. 
Kegiatan pengabdian masyarakat ini diharapkan dapat membantu warga dalam mengolah limbah biji karet dan menciptakan jiwa wirausaha dalam diri warga dengan menjadikan produk yang akan disosialisasikan sebagai produk yang akan dipasarkan. Pemasaran produk biji karet juga dapat menjadi lahan yang menjanjikan bagi warga dengan melakukan pembentukan UMKM.

\section{METODE PELAKSANAAN}

\section{Waktu dan Tempat}

Kegiatan pengabdian pada masyarakat ini dilakukan di rumah ibu RT 02 Desa Suka Maju Muaro Jambi pada tanggal 06 Agustus 2020.

\section{Metode}

Berdasarkan permasalahan yang ada maka dilakukan kegiatan-kegiatan berupa sosialisasi dan penerapan langsung di lapangan. Metode yang dilakukan pada kegiatan PPM ini adalah:

1. Tahap 1. Kegiatan yang dilakukan adalah sosialisasi cara mereduksi HCN pada biji karet hingga aman konsumsi dengan metode perendaman dan perebusan sebelum dijadikan penepungan sehingga menghasilkan tepung biji karet yang aman. Selanjutnya dilakukan dengan langsung membuat tortilla chip bersama-sama dengan ibu-ibu RT 02 Desa Suka Maju untuk lebih memahami cara pembuatannya, sehingga semua peserta diharapkan dapat membuat tortilla chip dari biji karet secara mandiri nantinya dan dapat membentuk kelompok usaha UMKM sendiri.

2. Tahap 2. Sosialisasi Teknik packaging dengan menggunakan plastik yang dapat dikemas menggunakan sealer sehingga dapat menambah nilai jual dari produk yang dihasilkan.

\section{Kontribusi Mitra}

Partisipasi Mitra pada pelaksanaan pengabdian pada masyarakat ini adalah

1) Mengumpulkan ibu-ibu RT 02 Desa Suka Maju Muaro Jambi

2) Menyediakan tempat pelaksanaan penyuluhan dan demonstrasi.

3) Menyediakan bahan dan alat pendukung.

\section{TARGET DAN LUARAN}

Target Dan Luaran Yang Dicapai

Target yang telah dicapai pada tahap 1 dan tahap 2 disajikan pada Tabel 1 .

Tabel 1. Target Tahap 1 dan 2 dari kegiatan Di RT 02 Desa Suka Maju

\begin{tabular}{|l|l|l|}
\hline No & Target Tahap 1 & Target Tahap 2 \\
\hline 1 & $\begin{array}{l}\text { Produk Olahan: Tortilla Chip } \\
\text { berbasis biji karet } \\
\text { Luaran: Peningkatan wawasan ibu- } \\
\text { ibu RT 02 Desa Suka Maju }\end{array}$ & 1. Produk: Tortilla Chip \\
\hline
\end{tabular}


Tabel 2. Inovasi Pengolahan Tortilla Chip Berbasis Biji Karet

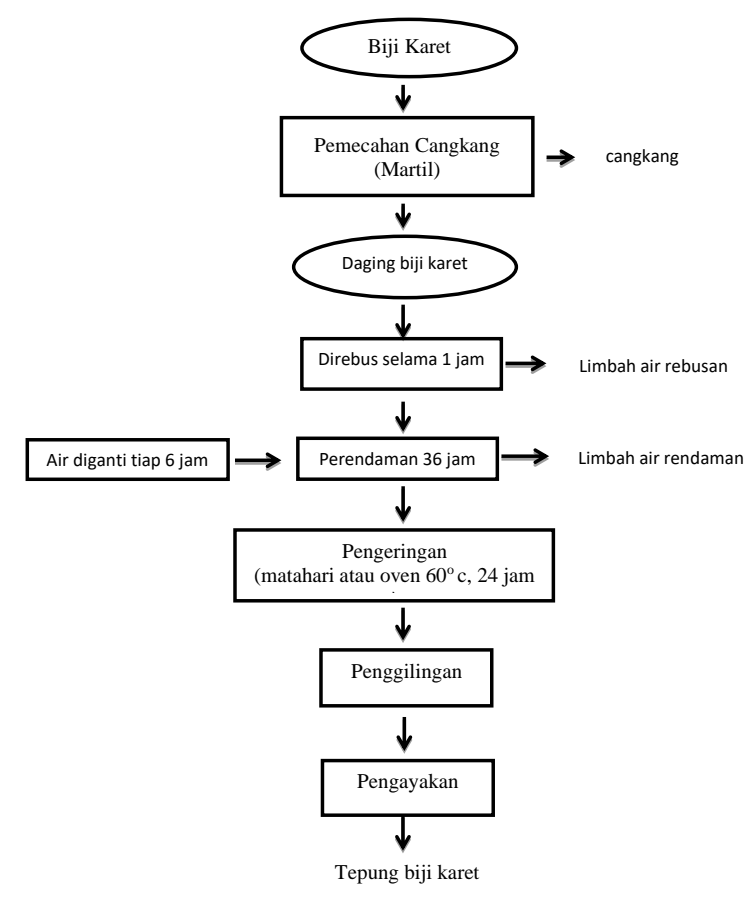

Gambar 1. Diagram Alir Pembuatan Tepung Biji Karet (Havea Brasiliensis)

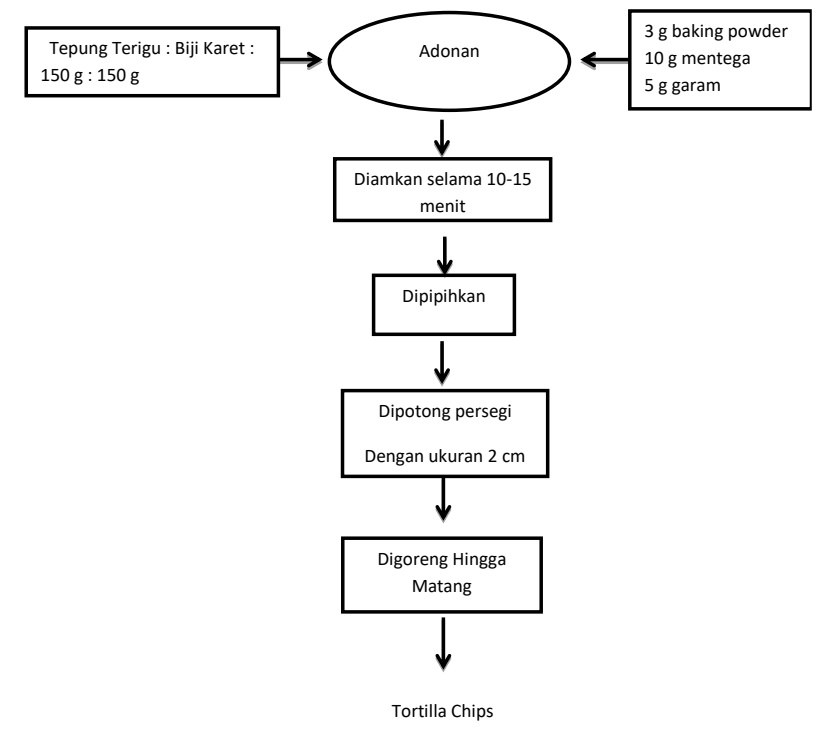

Gambar 2. Diagram Alir Pembuatan Tortilla chips

\section{HASIL KEGIATAN}

Kegiatan pengabdian pada masyarakat ini telah dilakukan bersama dengan ibu-ibu RT 02 Desa Suka Maju Muaro Jambi sebagai mitra. Kegiatan ini berlangsung tanggal 06 Agustus 2020 bertempat di rumah ibu RT 02 Desa Suka Maju yang dihadiri oleh 23 orang peserta. Adapun kegiatan yang dilakukan terdapat dalam 3 bentuk kegiatan. Kegiatan pertama adalah sosialisasi cara mereduksi HCN biji karet sebelum dibuat tepung biji karet, kegiatan kedua demo langsung kepada ibu-ibu tentang cara pembuatan tortilla chip dengan memanfaatkan tepung biji karet, dan kegiatan ketiga memberikan Teknik pemasaran dan melatih cara pengemasan produk.

Kegiatan diawali dengan melakukan registrasi peserta yang hadir, dikarenakan pelaksanaan bertepatan dengan siaga covid-19 maka kegiatan berlangsung dengan mengikuti protokol kesehatan dengan mengecek suhu tubuh peserta, mencuci tangan, memakai masker dan menjaga jarak. Setelah peserta berkumpul kemudian tim pengabdian memulai kegiatan dengan melakukan sosialisasi cara mereduksi atau mengurangi kadar HCN pada biji karet. Sosialisasi berlangsung dengan baik dan disambut dengan antusias peserta dikarenakan tidak banyak yang mengetahui bahwa biji karet dapat dikonsumsi, namun ada juga beberapa peserta yang telah pernah mengolah biji karet menjadi seperti kacang goreng. Para peserta banyak mengajukan pertanyaan mengenai teknik mengupas dan tahapan yang dilakukan untuk mengurangi $\mathrm{HCN}$ yang dikenal sebagian peserta dapat membuat "mabuk". 

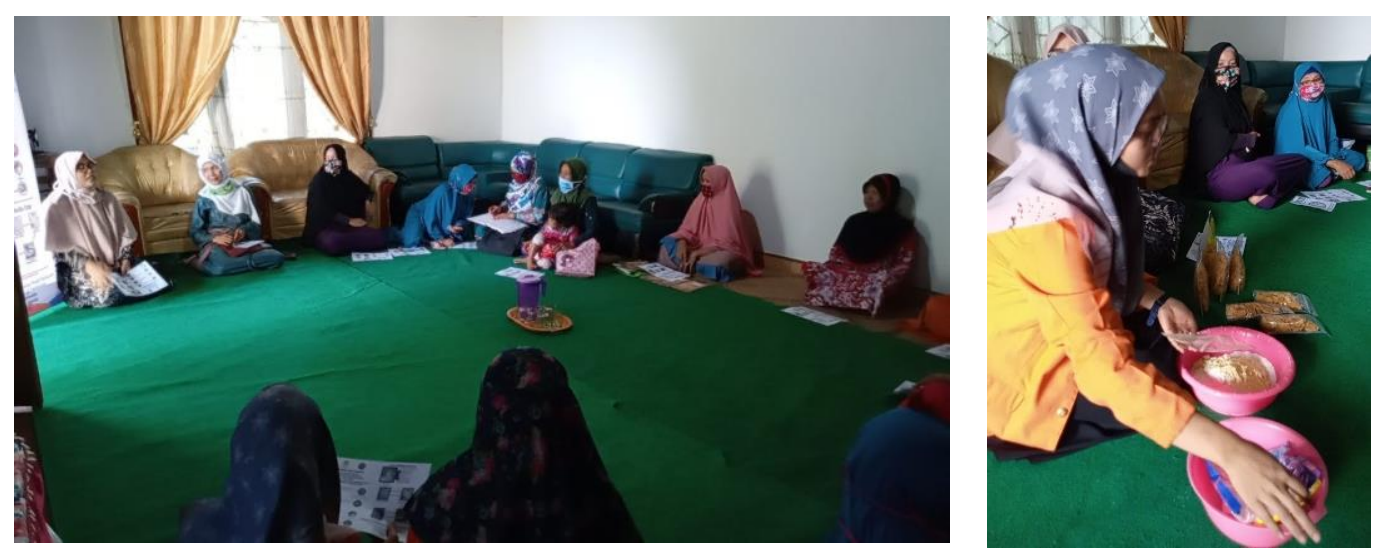

Gambar 2. Pemberian Sosialisasi dan demo oleh Tim Pengabdian Kepada Masyarakat

Kegiatan kedua yang dilakukan adalah demo kedua demo langsung kepada ibu-ibu tentang cara pembuatan tortilla chip dengan memanfaatkan tepung biji karet. Selama kegiatan kedua para peserta terlibat langsung dalam proses pembuatan Tortilla Chip dari biji karet. Setelah produk jadi selanjutnya diajarkan teknik pengemasan yang dapat dilakukan menggunakan sealer dan plastik. Dalam kegiatan ini juga disumbangkan kepada ibu-ibu RT 02 Desa Suka Maju alat pendukung usaha berupa pasta maker dan sealer.

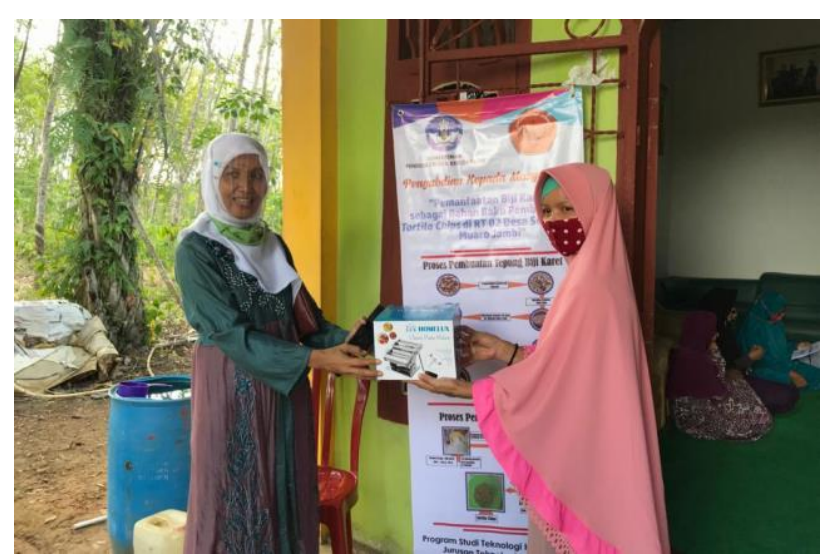

Gambar 3. Penyerahan alat pendukung usaha

\section{KESIMPULAN}

Kegiatan pengabdian pada masyarakat ini menambah pengetahuan ibu-ibu RT 02 Desa Suka Maju Muaro Jambi dalam hal mengolah biji karet menjadi tepung biji karet dan pembuatan Tortilla Chip biji karet. Selanjutnya butuh motivasi tinggi dari ibu-ibu RT 02 untuk membentuk UMKM pengolahan berbasis biji karet.

\section{UCAPAN TERIMAKASIH}

Kami mengucapkan terima kasih kepada Lembaga Penelitian dan Pengabdian Masyarakat (LPPM) Universitas Jambi yang telah mendanai dan melakukan dukungan hingga terlaksannya Pengabdian pada Masyarakat ini.

\section{DAFTAR PUSTAKA}

Karima R. 2015. Pengaruh Perendaman dan Perebusan Terhadap Kadar HCN Pada Biji Karet. Jurnal Riset Industri Hasil Hutan:7(1) 